\title{
Storage of soybean with high percentage of grains damaged by bugs in the crop $^{1}$
}

\author{
Jaqueline Ferreira Vieira Bessa ${ }^{2}$, Osvaldo Resende ${ }^{2 * \mathbb{D}}$, Rayr Rodrigues de Lima ${ }^{2}$ \\ Maria Aparecida da Silva Lopes ${ }^{2}$, Elivanio Santos Rosa ${ }^{2}$, Valdiney Cambuy Siqueira ${ }^{3}$
}

$10.1590 / 0034-737 X 202168030004$

\begin{abstract}
Bugs are pest insects that, when not adequately controlled, may cause significant losses in the soybean crop. Their damage to grains compromises delivery in the storage unit and storage success. Thus, the objective of this study was to evaluate, during storage, the effect of temperature and moisture content on soybean grain quality with high damage caused by bugs in the crop. The experiment was set in a completely randomized design with a $2 \times 4 \times 5$ factorial design, with two moisture contents (11.75 and $13.84 \%$ (w.b.)), four storage temperatures $\left(20,25,30\right.$ and $\left.35^{\circ} \mathrm{C}\right)$, and five evaluation periods (0, 2, 4, 6 and 8 months). The percentage of damaged/fermented, damaged, fermented, broken grains, and electrical conductivity were analyzed. It can be inferred that bug-damaged soybean grains have reduced quality when stored at higher temperatures and for more extended periods. It is not recommended to store bug-damaged grains in moisture contents of $13.84 \%$ (w.b.) at temperatures above $30^{\circ} \mathrm{C}$ for longer than four months. Grains stored at $35^{\circ} \mathrm{C}$ when not damaged by bugs, ferment after six months of storage. Bug-damaged grains evolve to fermented grains during storage.
\end{abstract}

Keywords: Glycine max; pest-insect; moisture content

\section{INTRODUCTION}

Brazil has shown a rising performance in terms of productivity and yield of soybean crop [Glycine $\max (\mathrm{L}$.) Merrill], in recent years (Gazolla Neto et al., 2015), standing out as the leading agricultural commodity in the country today (Conab, 2019).

Until harvest, field soybean cultivation is subject to attack by pests that can damage seed structure. The species complex, including defoliating caterpillars and bugs are the primary pests of soybean crops. When not properly controlled, those insects can cause significant economic losses (Bortoli et al., 2012). Bugs feed directly on seeds, causing damage through pod abscission at the early development of these organs, which causes wrinkling and deformation (Maziero et al., 2009). They inject salivary secretions into the seeds and ingest the food paste formed by the salivary enzymes (Depieri \& Panizzi, 2011).

The rules for commercialization and care according to the destination of the product are different for seeds that are marketed for field production, and those intended for human food as raw material for industries, which in this case are commonly denominated grains.

Before delivery in the storage, the grains are classified according to the commercial soybean standard of the country, regulated by Normative Instructions No. 11 of May 15, 2007 (IN 11/2007) and No. 37 of July 27. 2007 (IN 37/2007) of the Ministry of Agriculture, Livestock, and Supply (Brasil, 2007a; Brasil, 2007b). Those instructions determine defects, rules, and limits for the marketing of soybeans. Among the main faults are burnt, moldy, fermented, damaged, immature, and sterile grains.

\footnotetext{
Submitted on November $11^{\text {th }}, 2019$ and accepted on December $3^{\text {nd }}, 2020$.

${ }^{1}$ This work is part of the thesis of the first author.

${ }^{2}$ Instituto Federal de Educação, Ciência e Tecnologia de Goiás, Rio Verde, Goiás, Brazil. jaqueline@agricola.eng.br; osvaldo.resende@ifgoiano.edu.br; rodrigues.rayr5@gmail.com; maria.slopes94@gmail.com; elivanio@caramuru.com

${ }^{3}$ Universidade Federal da Grande Dourados, Dourados, Mato Grosso do Sul, Brazil. vcambuy@yahoo.com

*Corresponding author: osvaldo.resende@ifgoiano.edu.br
} 
Damage can make grains susceptible to reduced quality and rejection by the storage unit. Most of the grains produced in the crop are stored before crushing, where there may be a natural reduction in physical, chemical, physiological, and/or sanitary qualities and result in low commercial value to the product.

In some Brazilian regions, environmental conditions are adverse for grain and seed storage due to high temperatures that may be associated with high relative humidity (Carvalho et al., 2014). Therefore, it is crucial to study the storage conditions to know the best way to keep the product for a long time without losing its essential characteristics to the final destination of the grains.

Thus, the objective of this study was to evaluate during storage, the effect of temperature and moisture content on the quality of soybeans with high damage caused by bugs in the crop.

\section{MATERIALAND METHODS}

This study was carried out at the Post-Harvest Laboratory of Plant Products (in Portuguese, LPCPV) of the Federal Institute of Education, Science and Technology Goiano (IF Goiano) - Rio Verde campus.

Soybean grains of 2014/15 crop from commercial crops that were attacked by bugs were collected in March 2015. The grains showed around $30 \%$ of the mass with damage caused by the bugs. The grains were processed in 3.00 $\mathrm{mm}$ circular classification sieve and $3.00 \times 22.00 \mathrm{~mm}$ oblong sieves for cleaning and separation of impurities. These grains were classified as group II which, according to NI 11/2007 (Brasil, 2007a), are intended for other uses, which will not be consumed in fresh.

Soybean grains were classified during each storage period by a qualified technician at the Ministry of Agriculture, Livestock, and Supply (MAPA), according to official standard ruled by Normative Instruction No. 11/2007 (Brasil, 2007a).

The samples were evaluated every two months through analysis of the moisture content, electrical conductivity, and official grain classification, where damaged grains, damaged grains showing a dark border considered fermentation by the official classifiers (damaged/fermented) and fermented grains that had no bug damage were detected. The percentage of total damaged grains was also performed.

In the method used to analyze the conditions of the soybeans to be delivered, the total percentage of damaged grains is divided by " 4 ". Damaged grains that are fermented are added to the fermented grains without division. In this work, the percentage of damaged/fermented grains was described and considered as an independent variable for the analysis of the phenomenon that occurs with pierced grains caused by bugs in the field.
The soybeans had an initial moisture content of $13.84 \%$ on a wet basis - w.b. After that, the total mass was divided into two samples, one part subjected to drying outdoors in a yard on plastic canvas in the sun, to reduce the moisture content up to $11.75 \%$ w.b., and consequently the water activity, to be stored later with safety.

A mass of $0.75 \mathrm{~kg}$ the soybeans were packed in highdensity polyethylene (HDPE) packages and then stored for eight months at four temperatures $(20,25,30$, and 35 ${ }^{\circ} \mathrm{C}$ ) and two moisture contents ( 11.75 and $13,84 \%$ w.b.). These packages hermetic were used to achieve reduced water vapor changes since the permeability rate of the HDPE used in the experiment is $0.02 \mathrm{~g}$ water ${ }^{-1} \mathrm{~d}^{-1}$ (Bessa et $a l ., 2015)$. The samples were stored in BOD (Biochemical Oxygen Demand) chambers set at different temperatures and, only open in previously determined evaluation periods.

Temperature and relative humidity inside the BOD were monitored employing a digital thermo-hygrometer recording them every 10 min during grain storage, shown in Table 1.

The moisture content of soybean grains was determined through gravimetry (Brasil, 2009), in a forced air circulation oven for $24 \mathrm{~h}$ at $105 \pm 3{ }^{\circ} \mathrm{C}$.

Electrical conductivity was performed according to the method described by Vieira \& Krzyzanowski (1999), and the reading was performed using a CD 850 digital conductivity meter.

The experiment was carried out using a completely randomized design, and the results were analyzed using a $2 \times 4$ x 5 factorial scheme, where it was used two moisture contents, four temperatures, five evaluation times in three replications. In relation to moisture content factor, the means were compared using the test of Tukey adopting the $5 \%$ significance level. Regarding time factor, regression analysis was done. For the variables that obtained interaction of the three factors, mathematical models based on the response surface were adjusted, and the models were selected based on the significance of the equation by the $\mathrm{F}$ test, adopting the $5 \%$ significance level, on the coefficient of determination $\left(\mathrm{R}^{2}\right)$ and knowledge of the evolution of the biological phenomenon.

The normality of the variables where all were normal was analyzed through the Shapiro-Wilk test with the aid of the Action Stat software.

\section{RESULTS AND DISCUSSION}

According to the summary of the analysis of variance for the analyzed variables shown in Table 2, there was an interaction of the initial moisture content $\mathrm{x}$ storage time. For the electrical conductivity, percentage of total damaged grains, percentage of damaged grains, damaged/ fermented grains, and fermented grains, an interaction of 
the three factors, initial moisture content $\mathrm{x}$ temperature $\mathrm{x}$ time, also occurred.

Soybeans grains were stored in initial moisture content of $11.75 \%$ (w.b.) near $12.0 \%$ (w.b.) recommended for safe storage (Smaniotto et al., 2014) and $13.84 \%$ (w.b.) near maximum moisture content of $14.0 \%$ (w.b.) established for product classification (Brazil, 2007a). The use of two moiture content conditions aims to meet a technical and commercial recommendation for culture in Brazil. Moisture contents differed in all storage periods, and it was possible to evaluate the difference in grain condition throughout storage (Table 3 ).

It was observed that the moisture content of grains stored with $11.75 \%$ (w.b.) decreased linearly during storage (Equation 1) but with an angular coefficient of 0.079, which represents the low slope of the line and small variation in moisture content during storage. On the other hand, grains stored with $13.84 \%$ (w.b.) not showed fluctuations in moisture content, so it was not statistically possible to mathematically represent the phenomenon. Both the reduction in moisture content during storage and its oscillation are common behaviors when it comes to biological and hygroscopic products. Virgolino et al. (2016) and Smaniotto et al. (2014) observed a reduction in soybean moisture content as a function of period and storage. In contrast, Bessa et al. (2015) did not observe model adjustment for the moisture content of crambe seeds stored in HDPE packaging.

According to Smaniotto et al. (2014), the variation in moisture content may be related to the permeability of the packaging used for the storage of grains and seeds, which are hygroscopic materials and subject to sorption pro-

Table 1: Means of temperature and relative humidity with the respective BOD standard deviations set at $20,25,30$, and $35^{\circ} \mathrm{C}$ during storage

\begin{tabular}{lcccc}
\hline \multirow{2}{*}{ Means } & \multicolumn{4}{c}{ Storage Temperatures $\left({ }^{\circ} \mathbf{C}\right)$} \\
\cline { 2 - 5 } & $\mathbf{2 0}$ & $\mathbf{2 5}$ & $\mathbf{3 0}$ & $\mathbf{3 5}$ \\
\hline Temperature ${ }^{\circ} \mathrm{C}$ & $21.02 \pm 2.15$ & $25.21 \pm 1.66$ & $29.09 \pm 0.47$ & $34.35 \pm 0.82$ \\
Relative humidity $(\%)$ & $75.69 \pm 12.28$ & $47.46 \pm 16.62$ & $45.46 \pm 12.66$ & $30.60 \pm 17.47$ \\
\hline
\end{tabular}

Table 2: Summary of analysis of variance with values of the mean square of variables initial moisture content (MC), electric conductivity (EC), total damaged grain percentage (TDG), damaged grain percentage (Dam), damaged/fermented (Dam/Fer) and fermented (Fer) of soybean grains damaged by bugs in the crop at different storage conditions

\begin{tabular}{|c|c|c|c|c|c|c|c|}
\hline \multirow{2}{*}{ SV } & \multirow{2}{*}{ DF } & \multirow{2}{*}{$\frac{\text { MC }}{(\% \text { w.b. })}$} & \multirow{2}{*}{$\frac{\mathrm{EC}}{\left(\mu \mathrm{S} \mathrm{cm}^{-1} \mathrm{~g}^{-1}\right)}$} & \multirow{2}{*}{$\begin{array}{c}\text { TDG } \\
\%)\end{array}$} & \multirow{2}{*}{$\begin{array}{c}\text { Dam } \\
(\%)\end{array}$} & \multirow{2}{*}{$\frac{\text { Dam/Fer }}{(\%)}$} & \multirow{2}{*}{$\begin{array}{l}\text { Fer } \\
(\%)\end{array}$} \\
\hline & & & & & & & \\
\hline $\mathrm{MC}$ & 1 & $159.38^{* *}$ & $2.11 \times 10^{4 * *}$ & $1,879.34^{* *}$ & $0.99^{\mathrm{NS}}$ & $1126.45^{* * *}$ & $75.3^{* *}$ \\
\hline TPE & 3 & $0.048^{\mathrm{NS}}$ & $8.93 \times 10^{4 * *}$ & $1,487.76^{* *}$ & $33.71^{* *}$ & $1299.15^{* * *}$ & $75.3^{* *}$ \\
\hline $\mathrm{TP}$ & 4 & $0.63^{* *}$ & $9.87 \times 10^{4 * *}$ & $967.59^{* *}$ & $46.86^{* *}$ & $732.38^{* *}$ & $49.4^{* *}$ \\
\hline MCXTPE & 3 & $0.05^{\mathrm{NS}}$ & $3.60 \times 10^{3 * *}$ & $522.10^{* *}$ & $6.90^{* *}$ & $290.67^{* *}$ & $75.3^{* *}$ \\
\hline MCxTP & 4 & $0.38^{* *}$ & $5.31 \times 10^{3 * *}$ & $330.76^{* *}$ & $9.74^{* *}$ & $224.21^{\text {*** }}$ & $49.4^{* *}$ \\
\hline TPExTP & 12 & $0.03^{\mathrm{NS}}$ & $9.90 \times 10^{3 * *}$ & $428.17^{* *}$ & $6.23^{* *}$ & $288.68^{* *}$ & $49.4^{* *}$ \\
\hline МСхТРЕхТP & 12 & $0.07^{\mathrm{NS}}$ & $974.82^{* *}$ & $172.65^{* *}$ & $2.24^{* *}$ & $77.59^{* * *}$ & $49.4^{* *}$ \\
\hline Residue & 80 & 0.033 & 45.42 & 3.53 & 0.42 & 3.00 & 0.07 \\
\hline $\mathrm{CV} \%$ & & 1.44 & 4.06 & 10.62 & 10.54 & 16.16 & 32.59 \\
\hline Mean & 12.60 & 165.82 & 17.70 & 6.17 & 10.73 & 0.79 & \\
\hline
\end{tabular}

SV: source of variation; DF: degree of freedom; MC: moisture content; TPE: temperature; TP: time; CV: coefficient of variation. ${ }^{* *}$ Significant at $1 \%$ by the F test; *Significant at $5 \%$ by the F test; ${ }^{\text {Ns }}$ Not-significant. TDG: sum of the damaged/fermented grains, damaged grains, and fermented grains.

Table 3: Means of moisture content (\% w.b.) in soybean grains stored at different moisture content as a function of the storage period

\begin{tabular}{|c|c|c|c|c|c|c|}
\hline \multicolumn{7}{|c|}{ Moisture content (\% w.b.) } \\
\hline \multirow[t]{2}{*}{$\mathrm{MCi}$} & \multicolumn{5}{|c|}{ Storage period (months) } & \multirow[t]{2}{*}{ Equation } \\
\hline & $\mathbf{0}$ & 2 & 4 & 6 & 8 & \\
\hline 12 & $11.75 \mathrm{a}$ & $11.48 \mathrm{a}$ & $11.66 \mathrm{a}$ & $11.31 \mathrm{a}$ & $11.04 \mathrm{a}$ & $\mathrm{MC}=-0.079 t+11.765 ; \mathrm{R}^{2}=0.7834$ \\
\hline 14 & $13.84 \mathrm{~b}$ & $13.70 \mathrm{~b}$ & $13.74 \mathrm{~b}$ & $13.76 \mathrm{~b}$ & $13.70 \mathrm{~b}$ & NS \\
\hline
\end{tabular}

Equal letters in the same column are not different from each other by the test of Tukey at 5\% of significance. MCi: Initial moisture content. MC: Moisture content. NS: not significant; t: storage period, months. 
cesses. Also, moisture content always tends to balance with temperature and relative humidity of the storage environment.

Grains stored in $13.84 \%$ moisture content (w.b.) initially presented a higher percentage of total damaged grains (Table 4). However, for both $11.75 \%$ and $13.84 \%$ moisture content, grains were classified as non-standard, as a maximum of $8 \%$ damage grains are allowed for commercialization and delivery (Brasil, 2007a). In the second and fourth months, no difference was found, when compared to grains stored with lower moisture content, except for the fourth month at $35^{\circ} \mathrm{C}$, when grains stored with moisture content of $13.84 \%$ (w.b.) showed 8.66 percentage points higher than grains stored with moisture content of $11.75 \%$ (w.b.). This behavior may be associated with the stress condition to which the product was submitted. Araújo et al. (2017), when studying the quality of stored soybean grains at temperatures of 17-20, 25-27 and $30{ }^{\circ} \mathrm{C}$, observed the occurrence of moldy grains from the first month of storage at the highest temperature, with a significant increase of fermented grains at high temperatures from the third month.

In the sixth and eighth month, there was no difference in the percentage of total damaged grains in grains stored at $20^{\circ} \mathrm{C}$. In the other storage temperatures, the grain stored in $13.84 \%$ moisture content (w.b.) showed more significant damage, especially the eighth storage period, at $35{ }^{\circ} \mathrm{C}$ when the grain at the highest moisture content was $83.50 \%$ of damaged grains, which results in values ten times higher than recommended by the Brazilian delivery rules. Higher moisture content is associated with a higher metabolic rate and, consequently, the deterioration process of stored grains is more pronounced (Araújo et al., 2017). The storage in high temperatures and moisture contents promote the oxidative and hydrolytic rancidity of soybean oil, darkening of the grains and reduction of unsaturated fatty acids, which play an important nutritional role (Pohndorf et al., 2018).

As temperature and time increased, the percentage of total damaged grains also increased (Figure 1). These results corroborate those obtained by Alencar et al. (2009) who stored soybean grains in moisture contents of 11.2, 12.8 and $14.8 \%$ (w.b.) at temperatures of 20,30 and $40{ }^{\circ} \mathrm{C}$ and observed that the grains stored at 12.8 and $14.8 \%$ showed 8.11 and $8.61 \%$ of damaged grains at $40{ }^{\circ} \mathrm{C}$, from 135 and 90 days, respectively, were considered off the basic commercialization standard. At 180 days, the grains stored in the highest moisture content had $14.31 \%$ of damaged grains.

Grains stored at $13.84 \%$ (w.b.) showed higher magnitudes (Figure 1B) in the percentage of total damaged grains (\% TDG) compared to those stored at $11.75 \%$ (w.b.) (Figure $1 \mathrm{~A}$ ), confirming that the $13.84 \%$ (w.b.) water is inadequate to store soybeans for long periods under these conditions, corroborating with Smaniotto et al. (2014), where they recommend storing soybeans for tropical conditions in $12 \%$ (w.b.). According to Carvalho \& Nakagawa (2012), higher moisture content promotes a rise in temperature and the respiratory activity of seeds, as well as of the microorganisms.

Regardless of the initial storage moisture content, as temperature increased, an increase of \% TDG occurred in the eighth month, highlighting that higher temperatures and storage time has a negative influence on the quality of soybean attacked by bugs and later stored.

Table 5 shows the means of the percentage of grains damaged by bugs in the crop. Until the fourth month, the grains stored in $13.84 \%$ (w.b.) of moisture content

Table 4: Total damaged soybean grain percentage (\%) in different moisture content at different temperatures over storage

\begin{tabular}{|c|c|c|c|c|c|}
\hline \multirow{3}{*}{$\begin{array}{l}\text { Storage period } \\
\text { (months) }\end{array}$} & \multirow{3}{*}{$\begin{array}{l}\text { Initial moisture } \\
\text { content (\% w.b.) }\end{array}$} & \multicolumn{4}{|c|}{ Total damaged grains $(\%)$} \\
\hline & & \multicolumn{4}{|c|}{ Temperature $\left({ }^{\circ} \mathbf{C}\right)$} \\
\hline & & 20 & 25 & 30 & 35 \\
\hline \multirow{2}{*}{0} & 11.75 & $12.29 \mathrm{a}$ & $12.29 \mathrm{a}$ & $12.29 \mathrm{a}$ & $12.29 \mathrm{a}$ \\
\hline & 13.84 & $17.46 \mathrm{~b}$ & $17.46 \mathrm{~b}$ & $17.46 \mathrm{~b}$ & $17.46 \mathrm{~b}$ \\
\hline \multirow{2}{*}{2} & 11.75 & $9.30 \mathrm{a}$ & $9.10 \mathrm{a}$ & $13.40 \mathrm{a}$ & $12.62 \mathrm{a}$ \\
\hline & 13.84 & $11.47 \mathrm{a}$ & $9.77 \mathrm{a}$ & $12.48 \mathrm{a}$ & $12.72 \mathrm{a}$ \\
\hline \multirow{2}{*}{4} & 11.75 & $12.56 \mathrm{a}$ & $12.86 \mathrm{a}$ & $12.79 \mathrm{a}$ & $15.48 \mathrm{a}$ \\
\hline & 13.84 & $14.19 \mathrm{a}$ & $13.79 \mathrm{a}$ & $15.20 \mathrm{a}$ & $24.14 b$ \\
\hline \multirow{2}{*}{6} & 11.75 & $13.57 \mathrm{a}$ & $10.11 \mathrm{a}$ & $11.12 \mathrm{a}$ & $19.40 \mathrm{a}$ \\
\hline & 13.84 & $12.23 \mathrm{a}$ & $14.61 \mathrm{~b}$ & $20.64 \mathrm{~b}$ & $52.12 \mathrm{~b}$ \\
\hline \multirow{2}{*}{8} & 11.75 & $11.31 \mathrm{a}$ & $14.00 \mathrm{a}$ & $18.51 \mathrm{a}$ & $29.51 \mathrm{a}$ \\
\hline & 13.84 & $13.47 \mathrm{a}$ & $19.13 \mathrm{~b}$ & $33.79 \mathrm{~b}$ & $83.50 \mathrm{~b}$ \\
\hline
\end{tabular}

Means followed by the same letter within the column and at the same period are not different from each other by the test of Tukey at $5 \%$ of significance.

Rev. Ceres, Viçosa, v. 68, n.3, p. 185-193, may/jun, 2021 
showed more considerable damage caused by the bugs in the crop; except in the fourth month at a temperature of $35{ }^{\circ} \mathrm{C}$, when they presented 1.50 percentage points lower than the grains stored at $11.75 \%$ (w.b.) because at this point, the percentage of damaged/fermented grains increased (Table 6).

Bug-damaged grains in the crop have whitish-colored damaged tissues, which vary according to the depth of the damage caused by the bug. When damaged grains have a dark border surrounding the damage caused by pests, they are considered as fermented grains. In 11/2007, fermented grains show higher depreciation compared to damaged grains in the light defect scale; also, they are accounted as fermented grains (fermented in the normative). However, in this study, they were individually sorted to detect the extent to which the color of this damage varies.

As the damaged/fermented grain variable increased, the number of damaged grains decreased. The rise in the temperature and storage time reduces damaged grains, and this is clearer in grains stored in the highest moisture content (Figure 2B). For the lowest moisture content, there was no significant model adjustment, with Figure 2A only representing the dispersion of the observed data.

Grains damaged at the beginning of storage have evolved to ferment over time and are no longer considered damaged grains in the official classification. The higher the temperature and the moisture content, the more pronounced was this evolution around the damage caused by the bug (Figure 3).

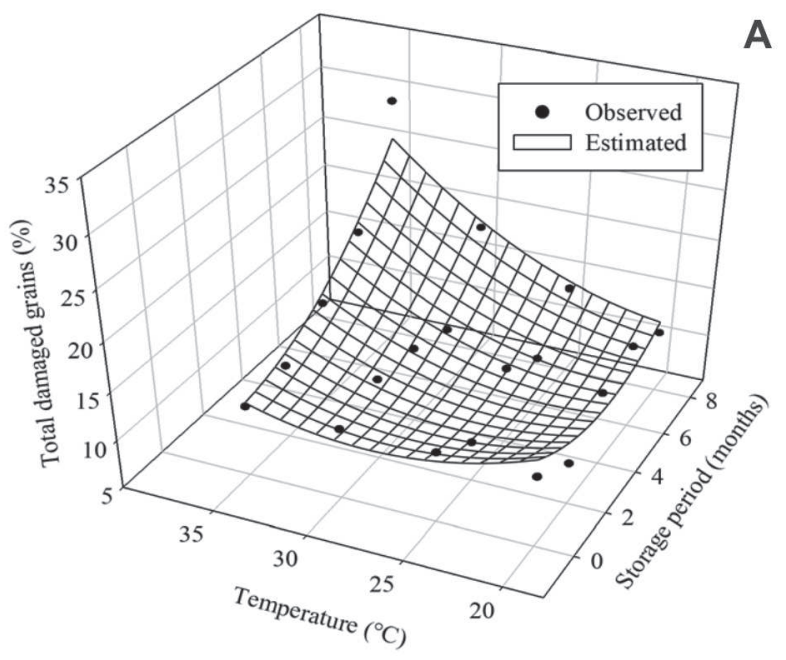

$\mathrm{TDG}=46.3108-4.0311 \mathrm{t}-2.4908 \mathrm{~T}+0.1739 \mathrm{t}^{2}+0.0437 \mathrm{~T}^{2}+0.1224 \mathrm{t} ; \mathrm{R}^{2}=0.8059$

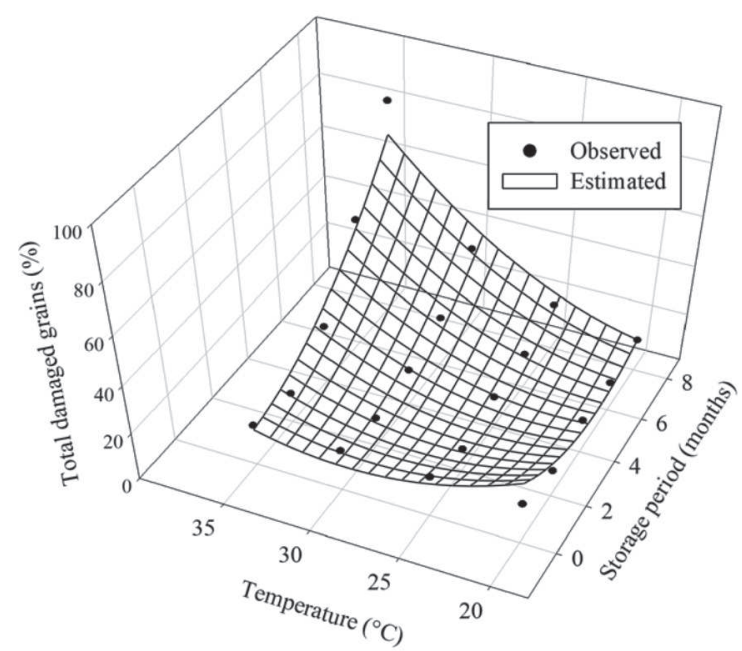

TDG $=158.5735-18.6417 \mathrm{t}-9.9819 \mathrm{~T}+0.7088 \mathrm{t}^{2}+0.1686 \mathrm{~T}^{2}+0.5686 \mathrm{t} ; \mathrm{R}^{2}=0.8801$

Figure 1: Percentage of total damaged grains in the initial moisture content of 11.75 (A) and 13.84\% (w.b.) (B), at different temperatures in an eight-month period. T: Storage temperature, ${ }^{\circ} \mathrm{C}$; t: storage period, months.

Table 5: Percentage of bug-damaged soybean grains (\%) in different moisture content and temperature over the storage period

\begin{tabular}{|c|c|c|c|c|c|}
\hline \multirow{3}{*}{$\begin{array}{l}\text { Storage period } \\
\text { (months) }\end{array}$} & \multirow{3}{*}{$\begin{array}{l}\text { Initial moisture } \\
\text { content ( } \% \text { w.b.) }\end{array}$} & \multicolumn{4}{|c|}{ Total damaged grains (\%) } \\
\hline & & \multicolumn{4}{|c|}{ Temperature $\left({ }^{\circ} \mathrm{C}\right)$} \\
\hline & & 20 & 25 & 30 & 35 \\
\hline \multirow{2}{*}{0} & 11.75 & $7.63 \mathrm{a}$ & $7.63 \mathrm{a}$ & $7.63 \mathrm{a}$ & $7.63 \mathrm{a}$ \\
\hline & 13.84 & $8.78 \mathrm{~b}$ & $8.78 \mathrm{~b}$ & $8.78 \mathrm{~b}$ & $8.78 \mathrm{~b}$ \\
\hline \multirow{2}{*}{2} & 11.75 & $4.83 \mathrm{a}$ & $4.37 \mathrm{a}$ & $4.00 \mathrm{a}$ & $3.62 \mathrm{a}$ \\
\hline & 13.84 & $6.20 \mathrm{~b}$ & $4.97 \mathrm{a}$ & $5.75 \mathrm{~b}$ & $5.05 \mathrm{~b}$ \\
\hline \multirow{2}{*}{4} & 11.75 & $6.56 \mathrm{a}$ & $6.66 \mathrm{a}$ & $6.59 \mathrm{a}$ & $6.68 \mathrm{~b}$ \\
\hline & 13.84 & $8.26 \mathrm{~b}$ & $7.92 \mathrm{~b}$ & $7.94 \mathrm{~b}$ & $5.08 \mathrm{a}$ \\
\hline \multirow{2}{*}{6} & 11.75 & $7.99 \mathrm{~b}$ & $6.49 \mathrm{a}$ & $5.39 \mathrm{a}$ & $3.83 \mathrm{~b}$ \\
\hline & 13.84 & $6.88 \mathrm{a}$ & $8.07 \mathrm{~b}$ & $5.83 \mathrm{a}$ & $0.99 \mathrm{a}$ \\
\hline \multirow{2}{*}{8} & 11.75 & $6.54 \mathrm{a}$ & $6.40 \mathrm{a}$ & $6.47 \mathrm{~b}$ & $4.61 \mathrm{~b}$ \\
\hline & 13.84 & $6.61 \mathrm{a}$ & $6.25 \mathrm{a}$ & $3.94 \mathrm{a}$ & $0.31 \mathrm{a}$ \\
\hline
\end{tabular}

Means followed by the same letter within the column and in the same period are not different from each other by the test of Tukey at $5 \%$ of significance. 
The grains were stored with a 3.91-percentage points difference in the percentage of damaged/fermented grains (Table 6) between moisture contents, differing in the initial period. In the second and fourth month of storage, no difference was found between moisture contents, only at the temperature of $35^{\circ} \mathrm{C}$ (fourth month), where the grain stored at $13.84 \%$ (w.b.) showed $19.07 \%$ of damaged/ fermented grain. Such a period coincided with the reduction in the percentage of damaged grains (Table 5), showing the point at which the increase in the fermentation of bug-damaged grains was most evident.

In the sixth and eighth month of storage at temperatures of 30 and $35^{\circ} \mathrm{C}$, the differences in damaged/ fermented grains were very significant between the grains stored in the two moisture contents (Table 6). Such a fact stated that higher temperatures combined with long storage periods increase the fermentation of grains that were damaged by bugs in the crop. This fact is shown in
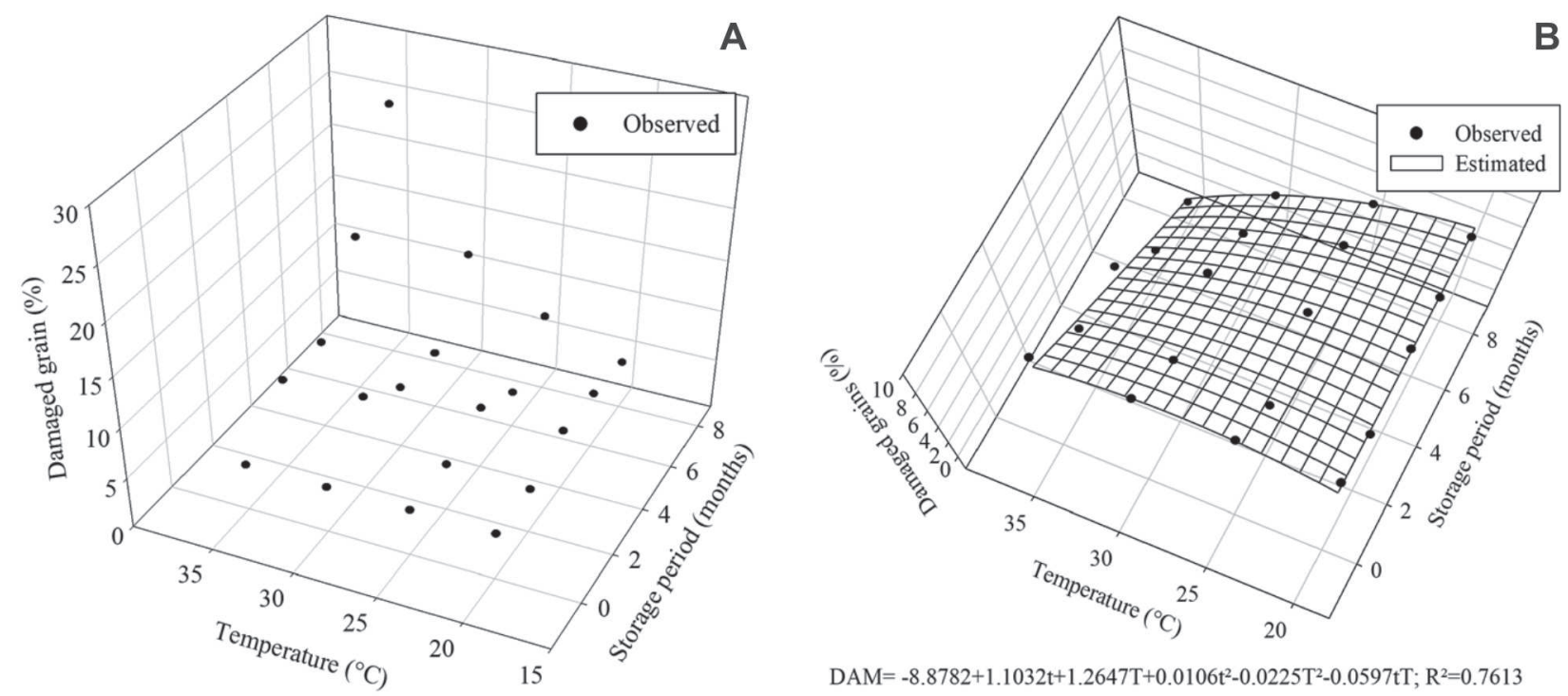

$\mathrm{DAM}=-8.8782+1.1032 \mathrm{t}+1.2647 \mathrm{~T}+0.0106 \mathrm{t}^{2}-0.0225 \mathrm{~T}^{2}-0.0597 \mathrm{tT} ; \mathrm{R}^{2}=0.7613$

Figure 2: Experimental and observed values of soybean damaged grain percentage, damaged in the crop as a function of temperature and period for the initial moisture content of 11.75 (A) and $13.84 \%$ w.b. (B). T: storage temperature, ${ }^{\circ} \mathrm{C}$; t: storage time, months; DAM: damaged grains.

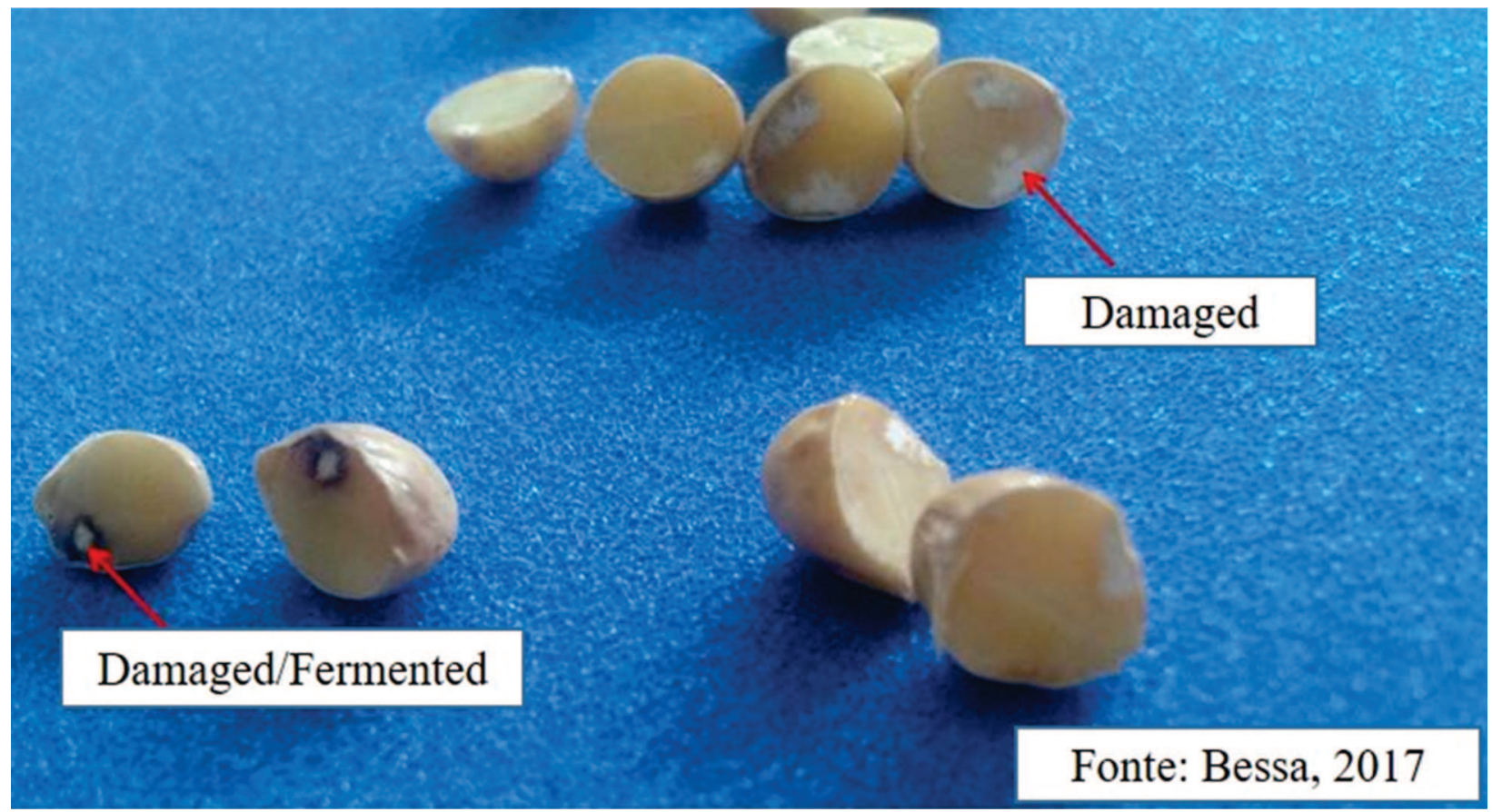

Figura 3: Soybean damaged by bug and grain showing insect damage and fermentation around the puncture (Bessa, 2017). 
Figure 4, where the increase in storage time and temperature results in higher values of damaged/ fermented grains as the grains that were stored with damage caused by bugs in the crop showed a gradual fermentation over storage.

Fermented grains that did not show damage caused by bugs in the classification occurred only in storage with $13.84 \%$ (w.b.) of moisture content in the sixth and eighth months, with 5.22 and $26.47 \%$, respectively, at $35^{\circ} \mathrm{C}$. The association of higher moisture content, high temperature, and storage time harm soybean storage, regardless of the damage caused by the insects.

The electrical conductivity of soybean grains (Table 7) was higher in grains, with the initial moisture content of $11.75 \%$ (w.b.). In the second month of evaluation, a difference was observed only in the temperature of $35^{\circ} \mathrm{C}$, where the electrical conductivity was higher in the grain stored at $13.84 \%$ (w.b.). Grains stored at $11.75 \%$ (w.b.) may have shown a higher value of electrical conductivity in the initial period due to drying performed to reduce moisture content. Faroni et al. (2009) also observed the higher value of electrical conductivity in the initial period in soybeans with lower moisture content. The removal of water from grains may disrupt the cell membranes causing an increase in the electrical conductivity of the imbibition solution

In the fourth and sixth months, the grains stored in initial moisture content of $13.84 \%$ (w.b.) showed higher average electrical conductivity, except at $20^{\circ} \mathrm{C}$, where no difference was found. In the eighth month, the electrical

Table 6: Percentage of damaged/fermented gains in different moisture content and temperature over storage

\begin{tabular}{|c|c|c|c|c|c|}
\hline \multirow{3}{*}{$\begin{array}{l}\text { Storage period } \\
\text { (months) }\end{array}$} & \multirow{3}{*}{$\begin{array}{l}\text { Initial moisture } \\
\text { content ( } \% \text { w.b.) }\end{array}$} & \multicolumn{4}{|c|}{ Total damaged grains (\%) } \\
\hline & & \multicolumn{4}{|c|}{ Temperature $\left({ }^{\circ} \mathbf{C}\right)$} \\
\hline & & 20 & 25 & 30 & 35 \\
\hline \multirow{2}{*}{0} & 11.75 & $4.66 \mathrm{a}$ & $4.66 \mathrm{a}$ & $4.66 \mathrm{a}$ & $4.66 \mathrm{a}$ \\
\hline & 13.84 & $8.57 \mathrm{~b}$ & $8.57 \mathrm{~b}$ & $8.57 \mathrm{~b}$ & $8.57 \mathrm{~b}$ \\
\hline \multirow{2}{*}{2} & 11.75 & $4.47 \mathrm{a}$ & $4.73 \mathrm{a}$ & $6.73 \mathrm{a}$ & $7.67 \mathrm{a}$ \\
\hline & 13.84 & $5.27 \mathrm{a}$ & $4.80 \mathrm{a}$ & $9.40 \mathrm{a}$ & $9.00 \mathrm{a}$ \\
\hline \multirow{2}{*}{4} & 11.75 & $5.93 \mathrm{a}$ & $5.87 \mathrm{a}$ & $6.20 \mathrm{a}$ & $8.80 \mathrm{a}$ \\
\hline & 13.84 & $6.00 \mathrm{a}$ & $6.20 \mathrm{a}$ & $7.27 \mathrm{a}$ & $19.07 \mathrm{~b}$ \\
\hline \multirow{2}{*}{6} & 11.75 & $5.35 \mathrm{a}$ & $3.62 \mathrm{a}$ & $5.73 \mathrm{a}$ & $15.57 \mathrm{a}$ \\
\hline & 13.84 & $5.58 \mathrm{a}$ & $6.54 \mathrm{~b}$ & $14.81 \mathrm{~b}$ & $45.91 \mathrm{~b}$ \\
\hline \multirow{2}{*}{8} & 11.75 & $4.78 \mathrm{a}$ & $7.59 \mathrm{a}$ & $12.05 \mathrm{a}$ & $24.90 \mathrm{a}$ \\
\hline & 13.84 & $6.86 \mathrm{a}$ & $12.87 \mathrm{~b}$ & $29.85 \mathrm{~b}$ & $56.72 \mathrm{~b}$ \\
\hline
\end{tabular}

Means followed by the same letter within the column and in the same period are not different from each other by the test of Tukey at $5 \%$ of significance.
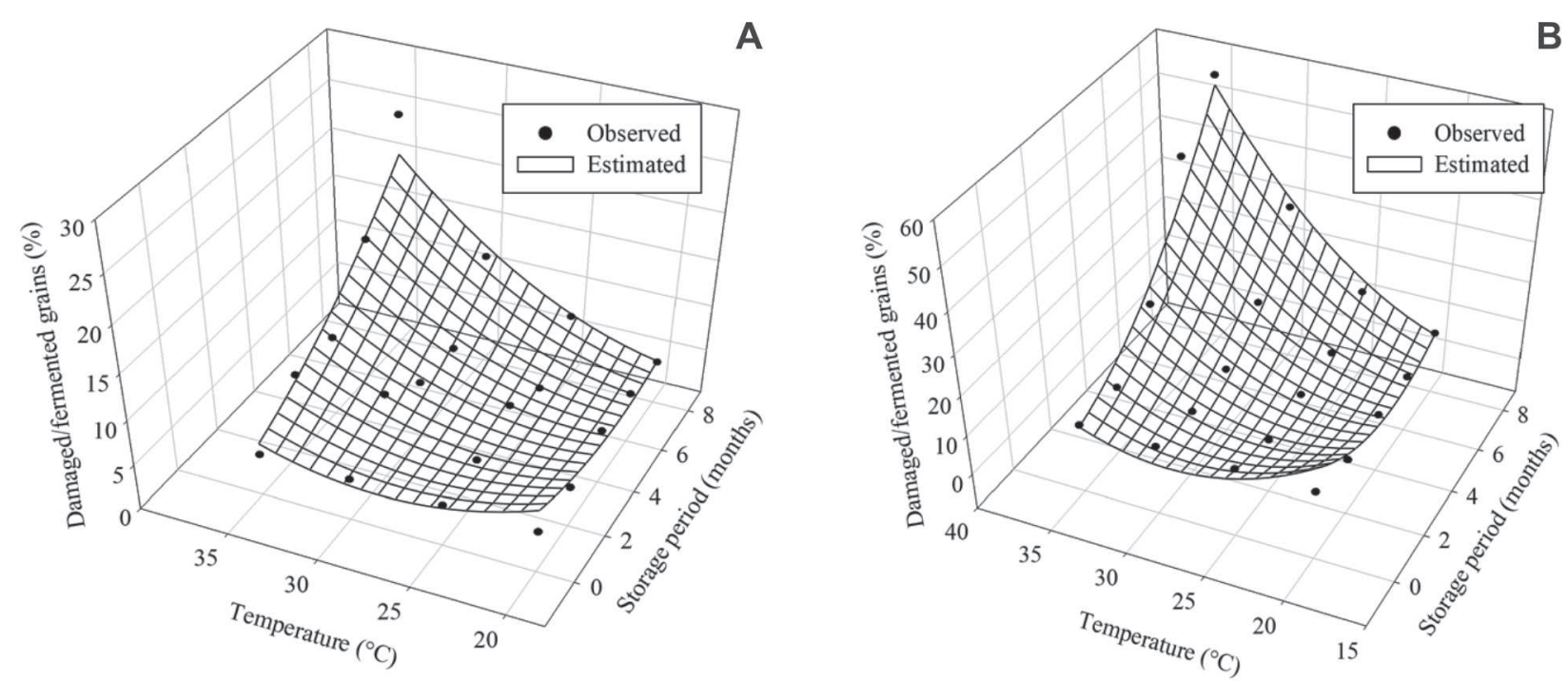

Figure 4: Observed and experimental values of the percentage of damaged/fermented soybean grains, damaged in the crop, as a function of temperature and time for the initial moisture contents of 11.75 (A) and $13.84 \%$ w.b. (B). T: storage temperature, ${ }^{\circ} \mathrm{C}$; $t$ : storage period, months; Dam/Fer: damaged/fermented grains. 
conductivity was higher in grains stored at $13.84 \%$ (w.b.) in all storage temperatures. The damage caused by the bugs to the soybean tegument evolved to fermentation, therefore favoring greater leaching of the solutes and, consequently, higher values of electrical conductivity of the imbibition solution.

Electrical conductivity increased as a function of storage time and temperature (Figure 5) in both initial moisture contents, corroborating the results obtained by Costa et al. (2010) in the storage of corn grains in bagsilos. The electrical conductivity of soybean grains with severe bug damage was more significant, considering the increase in moisture content, temperature, and storage time. Therefore, such conditions provided a stress condition to the product, which may have favored the intensity of metabolic activity, which associated with the piercing caused by the insect in the grains supported the increase of leaching and, consequently, loss of quality, since, according to Silva et al. (2014) this test indicates the level of organization of the cell membrane system and, indirectly, the level of the vigor of the sample.

When storing corn grains in two moisture contents (14.5 and $18.0 \%$ w.b.), Costa et al. (2010) described that in the higher moisture content, there was a process of faster membrane and cell wall deterioration, as observed in this study. Faroni et al. (2009) also found that, for the highest

Table 7: Electric conductivity $\left(\mu \mathrm{S} \mathrm{cm}^{-1} \mathrm{~g}^{-1}\right)$ of bug-damaged soybean grains in different moisture content and different temperatures over storage

\begin{tabular}{|c|c|c|c|c|c|}
\hline \multirow{3}{*}{$\begin{array}{l}\text { Storage period } \\
\text { (months) }\end{array}$} & \multirow{3}{*}{$\begin{array}{l}\text { Initial moisture } \\
\text { content ( } \% \text { w.b.) }\end{array}$} & \multicolumn{4}{|c|}{ Total damaged grains $(\%)$} \\
\hline & & \multicolumn{4}{|c|}{ Temperature $\left({ }^{\circ} \mathbf{C}\right)$} \\
\hline & & 20 & 25 & 30 & 35 \\
\hline \multirow{2}{*}{0} & 11.75 & $87.14 \mathrm{~b}$ & $87.14 \mathrm{~b}$ & $87.14 \mathrm{~b}$ & $87.14 \mathrm{~b}$ \\
\hline & 13.84 & $74.71 \mathrm{a}$ & $74.71 \mathrm{a}$ & $74.71 \mathrm{a}$ & $74.71 \mathrm{a}$ \\
\hline \multirow{2}{*}{2} & 11.75 & $103.84 \mathrm{a}$ & $105.54 \mathrm{a}$ & $123.76 \mathrm{a}$ & $147.72 \mathrm{a}$ \\
\hline & 13.84 & $95.80 \mathrm{a}$ & $111.19 \mathrm{a}$ & $125.13 \mathrm{a}$ & $175.97 \mathrm{~b}$ \\
\hline \multirow{2}{*}{4} & 11.75 & $115.79 \mathrm{a}$ & $124.27 \mathrm{a}$ & $154.50 \mathrm{a}$ & $226.06 \mathrm{a}$ \\
\hline & 13.84 & $113.38 \mathrm{a}$ & $136.18 \mathrm{~b}$ & $192.39 \mathrm{~b}$ & $331.94 \mathrm{~b}$ \\
\hline \multirow{2}{*}{6} & 11.75 & $130.93 \mathrm{a}$ & $139.62 \mathrm{a}$ & $194.20 \mathrm{a}$ & $296.67 \mathrm{a}$ \\
\hline & 13.84 & $126.97 \mathrm{a}$ & $172.76 \mathrm{~b}$ & $270.38 \mathrm{~b}$ & $362.26 \mathrm{~b}$ \\
\hline \multirow{2}{*}{8} & 11.75 & $130.49 \mathrm{a}$ & $167.81 \mathrm{a}$ & $225.75 \mathrm{a}$ & $310.08 \mathrm{a}$ \\
\hline & 13.84 & $144.96 \mathrm{~b}$ & $257.31 \mathrm{~b}$ & $305.37 \mathrm{~b}$ & $366.21 \mathrm{~b}$ \\
\hline
\end{tabular}

Means followed by the same letter within the column and in the same period are not different from each other by the test of Tukey at $5 \%$ of significance.

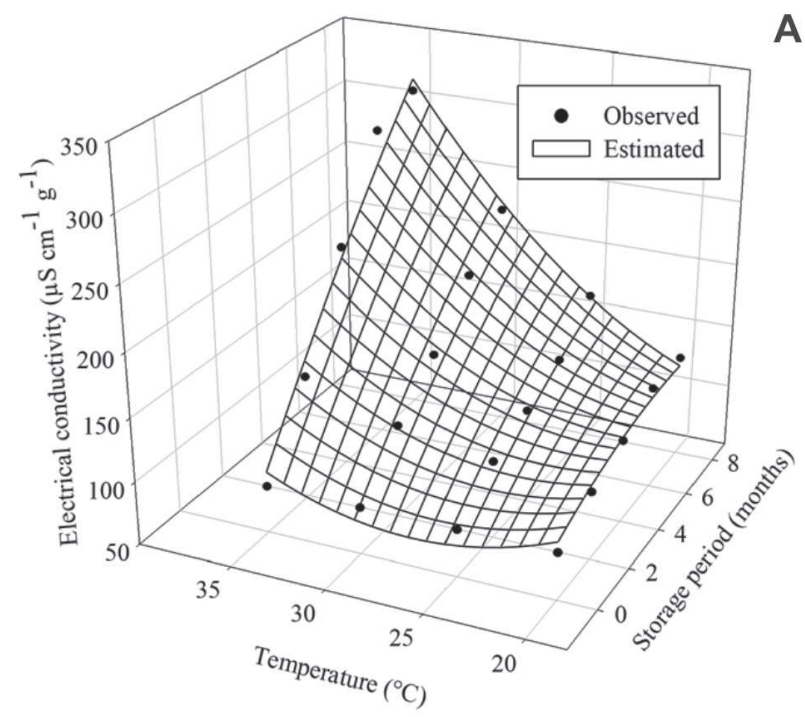

$\mathrm{EC}=399.7140-24.0302 \mathrm{t}-24.0406 \mathrm{~T}-0.5527 \mathrm{t}^{2}+0.4409 \mathrm{~T}^{2}+1.6010 \mathrm{tT} ; \mathrm{R}^{2}=0.9766$

A

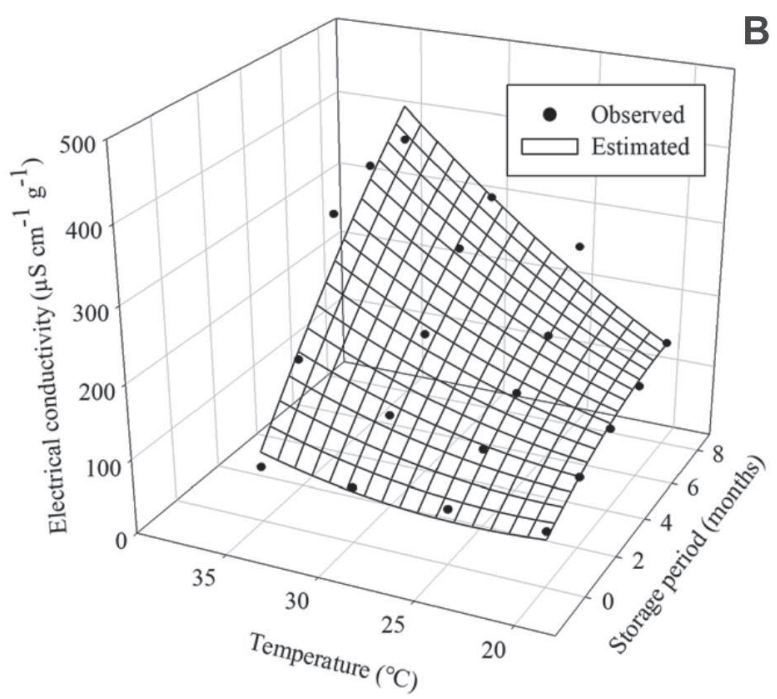

$E C=235.1829-20.8683 t-14.6707 T-1.0591 t^{2}+0.3046 T^{2}+1.9669 t T ; R^{2}=0$.

Figure 5: Observed and experimental values of electrical conductivity of soybean imbibition solution, damaged in the crop, as a function of temperature and period for moisture contents of 11.75 (A) and $13.84 \%$ w.b. (B). T: storage temperature, ${ }^{\circ} \mathrm{C}$; t: storage period, months; EC: electrical conductivity.

Rev. Ceres, Viçosa, v. 68, n.3, p. 185-193, may/jun, 2021 
moisture content, there was a significant increase in electrical conductivity due to the interaction of the evaluated silo-bag points and storage period when working with soybean stored in silo-bag for 180 days, with two different moisture contents, 13.3 and $17.4 \%$ (w.b.).

Grains stored in initial moisture content of $11.75 \%$ (w.b.) had average electrical conductivity from 87.14 to 296.67 $\mu \mathrm{S} \mathrm{cm} \mathrm{cm}^{-1} \mathrm{~g}^{-1}$ and grains stored with $13.84 \%$ (w.b.) ranged from 74.71 to $366.21 \mu \mathrm{S} \mathrm{cm}^{-1} \mathrm{~g}^{-1}$, where the lowest values are associated with the beginning and the highest, to the end of storage. The observation of higher electrical conductivity values for wetter grains and more extended storage periods was also described by Bessa et al. (2015) and Barbosa et al. (2010), respectively. However, the presence of a lesion previously occurred in the product, such as bed bug puncture, may have contributed to higher electrolyte leaching into soaking water.

\section{CONCLUSIONS}

High temperatures and longer storage periods increase the percentage of damaged/fermented grains, total damaged grains, and electrical conductivity, which results in loss of quality of bug-damaged soybean grains in the crop.

It is not recommended to store bug-attacked soybeans with moisture contents of $13.84 \%$ (w.b.) at temperatures higher than $30^{\circ} \mathrm{C}$ for longer than four months.

Bug-damaged grains evolve to fermented grains during storage.

Soybean grains stored in moisture content of $13.84 \%$ (w.b.) and temperature of $35^{\circ} \mathrm{C}$, which showed no damage caused by bugs, ferment after six months of storage.

\section{ACKNOWLEDGMENTS}

The authors extend thanks to IF Goiano, CAPES, FAPEG, FINEP and CNPq for their financial support, which was indispensable to the execution of this study.

The authors declare that there is no conflict of interest.

\section{REFERENCES}

Alencar ER, Faroni LRD, Lacerda Filho AF, Peternelli LA \& Costa AR (2009) Qualidade dos grãos de soja armazenados em diferentes condições. Revista Brasileira de Engenharia Agrícola e Ambiental, 13:606-613.

Araújo MMV, Caneppele MAB \& Trage AK (2017) Grãos de soja submetidos a diferentes condições de armazenamento. Nativa, $5: 79-84$.

Barbosa CZE, Smiderle OJ, Alves JMA, Vilarinho AA \& Sediyama T (2010) Qualidade de sementes de soja BRS Tracajá, colhidas em Roraima em função do tamanho no armazenamento. Revista Ciência Agronômica, 41:73-80.

Bessa JFV, Donadon JR, Resende O, Alves RMV, Sales JF \& Costa LM (2015) Armazenamento do crambe em diferentes embalagens e ambientes: Parte I - Qualidade fisiológica. Revista Brasileira de Engenharia Agrícola e Ambiental, 19:224-230.
Bessa JFV (2017) Armazenamento de grãos de soja com elevada danificação por percevejo na lavoura. Tese de Doutorado. Instituto Federal de Educação, Ciência e Tecnologia Goiano, Rio Verde. $127 \mathrm{p}$.

Bortoli SA de, Murata AT, Vacari AM, Bortoli CP \& Ramalho DG (2012) Herbivoria em soja: efeito na composição química das folhas e na biologia da lagarta da soja e do percevejo verde pequeno. Comunicata Scientiae, 3:192-198.

Brasil (2009) Ministério da Agricultura, Pecuária e Abastecimento. Secretaria Nacional de defesa Agropecuária. Regras para Análise de Sementes. Brasília, MAPA. 399p.

Brasil (2007a) Ministério da Agricultura, Pecuária e Abastecimento. Regulamento Técnico da Soja. DOU, 15/05/2007, Section 1, p.13-15.

Brasil (2007b) Ministério da Agricultura, Pecuária e Abastecimento. Altera padrão soja. DOU, 27/07/2007, Section 1, p. 9.

Carvalho ER, Mavaieie DPR, Oliveira JA, Carvalho MV \& Vieira AR (2014) Alterações isoenzimáticas em sementes de cultivares de soja em diferentes condições de armazenamento. Pesquisa Agropecuária Brasileira, 49:967-976.

Carvalho NM \& Nakagawa J (2012) Sementes: Ciência, Tecnologia e Produção. $5^{\text {th }}$ ed. Jaboticabal, FUNEP. 590p.

Conab - Companhia Nacional de Abastecimento (2019) Acompanhamento da safra brasileira de grãos - Safra 2018/19, N.12 - Décimo segundo levantamento - Setembro de 2019. Brasília, Conab. 47p.

Costa AR, Faroni LRD, Alencar ER, Carvalho MCS \& Ferreira LG (2010) Qualidade de grãos de milho armazenados em silos bolsa. Revista Ciência Agronômica, 41:200-207.

Depieri RA \& Panizzi AR (2011) Duration of feeding and superficial and in-depth damage to soybean seed by selected species of stink bugs (Heteroptera: Pentatomidae). Neotropical Entomology, 40:197-203.

Faroni LRA, Alencar ER, Paes JL, Costa AR \& Roma RCC (2009) Armazenamento de soja em silos tipo bolsa. Engenharia Agrícola, 29:91-100.

Gazolla Neto A, Fernandes MC, Gomes AD, Gadotti GI \& Villela FA (2015) Distribuição espacial da qualidade fisiológica de sementes de soja em campo de produção. Revista Caatinga, 28:119-127.

Maziero H, Guedes JVC, Farias JR, Rodrigues RB, Dalazen G \& Prá ED (2009) Volume de calda e inseticidas no controle de Piezodorus guildonii (Westwood) na cultura da soja. Ciência Rural, 39:1307-1312.

Pohndorf RS, Meneghetti VL, Paiva FF, Oliveira M, \& Elias MC (2018). Avaliação cinética da estabilidade oxidativa e degradação física de grãos de soja armazenados em diferentes condições. Journal of Food Processing and Preservation, 42:01-08.

Silva VN, Zambiasi CA, Tillmann MAA, Menezes NL \& Villela F (2014) Condução do teste de condutividade elétrica utilizando partes de sementes de feijão. Revista de Ciências Agrárias, 37:206-213.

Smaniotto TAS, Resende O, Marçal KAF, Oliveira DEC \& Simon GA (2014) Qualidade fisiológica das sementes de soja armazenadas em diferentes condições. Revista Brasileira de Engenharia Agrícola e Ambiental, 18:446-453.

Vieira RD \& Krzyzanowski FC (1999) Teste De Condutividade Elétrica. In: Krzyzanowski FC, Vieira RD \& França Neto JB (Eds.) Vigor de sementes: Conceitos e testes. Londrina, Abrates. p.01-26.

Virgolino ZZ, Resende O, Gonçalves DN, Marçal KAF \& Sales JF (2016) Physiological quality of soybean seeds artificially cooled and stored in different packages. Revista Brasileira de Engenharia Agrícola e Ambiental, 20:473-480. 